\title{
Enhancing Malaysian Primary Pupils' Vocabulary Skills using Pocable Game and Pear Deck
}

\author{
Chai Kar Ni, Bonaventure Jong, Mary Anne Dison, Sylvia Anak Thomas, \\ Melor Md Yunus* and Ashairi Suliman \\ Universiti Kebangsaan Malaysia, Bangi, Selangor, Malaysia \\ https://orcid.org/0000-0003-0258-3273 \\ https:// orcid.org/0000-0003-0754-6914 \\ https:// orcid.org/0000-0003-3150-2989 \\ https:// orcid.org/0000-0002-9576-8877 \\ https://orcid.org/0000-0001-7504-7143 \\ https://orcid.org/0000-0003-2796-9965
}

\begin{abstract}
The importance of teaching English as a second language has been given emphasis as stated in the Malaysian Education Blueprint (2013-2025). Previous studies had proven that it was extremely draining to teach vocabulary to pupils using conventional chalk and talk methods. Pupils were demotivated and they could not remember the words learned. Hence, this research was carried out to enhance and encourage pupils to learn vocabularies. Pocable is a form of game-based learning and is initiated based on the concept taken from two popular games known as "Scrabble Board Game" and "Chinese Play Card Game". Pear Deck was incorporated as an interactive online platform used to engage pupils in individual and social learning. In this quasi-experimental research, pre-test, post-test, and survey questionnaire were applied to collect data from 40 Year Four pupils of four rural schools in Sarawak ranging from Subis and Bintulu districts. The data collected were analysed descriptively. The findings of the research showed that majority of the respondents had improvements in their vocabulary skills and $4 \mathrm{C}^{\prime} \mathrm{s}$ (cooperation and collaboration, communication, creative and critical thinking skills) and $1 \mathrm{~V}$ (value). They were also encouraged to learn more vocabularies. This research had also shone some light on the potential use of Pocable Game as ESL learners had better memory retention of the vocabularies learned.
\end{abstract}

Keywords: Pocable Game; education; vocabulary; game-based learning; primary pupils 


\section{Introduction}

English language is the lingua franca of the modern world as it is the dominant language in international affairs (Thirusanku \& Yunus, 2012). In fact, English is the lingua franca for different levels such as local, regional, national and international. English as a Lingua Franca (ELF) is also the study of the type of language that is used when different second language speakers interact (McKay, 2018). English as a lingua franca (ELF) is the teaching and learning of English language as the medium of communication for different native languages speakers. However, English is the second language in Malaysia. Lie and Yunus (2018) also mentioned that English is the global language of interaction. It is crucial for a person's competencies development. This is because when a person is well proficient in English, this will enable them to excel in the Fourth Industrial Revolution. According to Reddy (2016), the market for English as a Second Language is booming. This is seen from the increased demand from the whole world towards both literacy and proficiency in the English language. According to Yunus and Ek Hern (2011), due to globalisation in the world today, the Malaysian government has taken different steps to maximise the usage of English in our education system. Thus, the learners opt to take English to enable them to become part of the global economy who can communicate effectively with others.

In Malaysia, the nation must acquire and learn English as a second language starting from the pre-school level. In fact, vocabulary is one of the core elements of language aptitude and reflects how well listeners listen, speak, read and write (Kunnu, Uiphant \& Sukwises, 2016). The importance of teaching English as a second language had been given emphasis in Malaysia so that pupils who are able to read and understand different English texts for information and enjoyment can be produced.

Bakhsh (2016) stated that vocabulary is fundamental to learn any language. With these vocabulary words, pupils are able to read and understand a reading passage in their textbook. However, it was undeniable that the pupils were demotivated and they were unable remember the spelling and meaning of the words learned. As asserted by Lim, Yunus and Amin (2017), the academic performance and dominant use of mother-tongue language had undeniably limited the pupils' experience in learning English and thus, affected their vocabulary exposure. Since the use of English vocabulary is limited within the school period, the pupils of Primary 4 had limited opportunity to use and learn the language naturally. Therefore, this had indirectly impacted the learning of English vocabulary, especially in remembering the spelling of the vocabulary. In the Primary 4 English Language textbook and Dokumen Standard Kurikulum dan Pentaksiran (DSKP), pupils are targeted to master and learn a list of High Frequency Words which are crucial for their language development within the six years of primary schooling. These stipulated words are vital in assisting pupils to acquire the necessary vocabulary insights that are related to the various themes and contents introduced in the syllabus. 
Thus, games would help the pupils to memorise and utilise new vocabularies more efficiently. According to Chirandon, Laohawiriyanon and Rakthong (2010), learning vocabularies through games could provide opportunities for target language practice, encourage the pupils to communicate by using all four language skills and create a real life situation for using language. The learning process could be enhanced through the use of technology. Incorporating Information and Communications Technology (ICT) in pupils' learning is undoubtedly a better teaching method as compared to the conventional chalk and talk method as learners were able to focus more through a fun and relaxing atmosphere of learning (Hashim, Rafiq \& Yunus, 2019). Hence, our aims for this research were to enhance Year Four pupils' vocabulary skills and to encourage learners to learn vocabularies using Pocable Game and Pear Deck.

\section{Literature Review}

\subsection{Teaching and Learning of Vocabulary}

Vocabulary is an important aspect in English language learning. It is the component that connects the four skills which are listening, speaking, reading and writing skill. In order to communicate well in the target language, pupils need to have enough number of words and they need to know how to apply them. Undoubtedly, it is a challenging task for English language teachers to equip primary pupils with adequate vocabulary even though many teaching strategies have been used to assist them in learning vocabulary (Yunus et al., 2020).

According to Indriyani and Sugirin (2019), vocabulary is imperative to be acquired by the learners. Recent studies in second and foreign language acquisition emphasised that non-native speakers need a good foundation of vocabulary knowledge in order to become successful English language users (Viera, 2016). Within the Malaysian context, the teaching and learning process of vocabulary in English language begins as early as Primary 1 and onwards to Primary 6 (Ministry of Education, 2017). The English language textbook has been the main source to teach and learn vocabulary through the different learning skills of listening, speaking, reading and writing. One of the criteria to teach and learn vocabulary is highlighted in the Standard Document for Primary School Curriculum, where after six years of primary schooling, pupils will be able to talk to their friends fluently in both formal and informal situations. They are also expected to be able to read and understand various English texts for information (Ministry of Education, 2017).

Through vocabulary, pupils will be able to comprehend and express language in better form. Learning vocabulary helps pupils to know words and use them in the correct context. Pupils must acquire vocabulary skill in order to get other skills such as listening, speaking, reading and writing. Even though pupils realised the importance of vocabulary, most of them find it challenging to acquire this skill due to the difficulties in remembering and retaining the new words learned. For a primary school English learner, acquiring vocabulary 
might be one of the concerns they faced. Hence, the use of teaching strategies to help improve this issue was imperative.

\subsection{Integrating ICT in Language Classroom}

Currently, the use of technology in the field of education has brought great impact to the process of teaching and learning. According to Yunus et al. (2014), the use of Information and Communication Technology (ICT) in education varies the teaching methods used in the class. In Malaysia, the use of technology has helped educators to adapt and develop several learning materials for the pupils to enrich their vocabulary. According to Noureddine (2017), the use of technology in a language classroom would contribute to positive language learning among learners. Therefore, many educationists have started using ICT to complement their teaching and learning activities. Similarly, many researchers agreed that technology provides children with a chance to learn four English skills not only within the class but also outside it by social interactions (Gee, 2005; Wang et al., 2008). In this paper, Pear Deck is used as a reinforcement tool to assist pupils in acquiring vocabulary skill. Pear Deck is an online learning site which was created by educators in order to support active learning among the pupils. It would also help to maximise the pupils' achievement and to improve interpersonal relationships as well as their self-esteem. The use of Pear Deck has been tested in thousands of real-world classrooms. Pear Deck has eased teachers' burden in creating active and collaborative learning environments in a language classroom. Thus, in this context, Pear Deck is used to support vocabulary learning in a fun and meaningful way.

\subsection{Using Game in Vocabulary Learning}

The use of games can facilitate the learning activities that teachers bring into their classroom. According to Taghiadeh et al. (2017), the use of games enables children to learn vocabulary better than using traditional ways. Shahriarpour and Kafi (2014) stated that using games makes pupils participate actively in the $21^{\text {st }}$ century technological society. Playing games which are educational to pupils would give a chance for them to experience a more positive and encouraging learning environment (Takeuchi \& Vaala, 2014). This is supported by Pomerantz and Bell (2007) who asserted that introducing educational games to pupils would create a fun and creative environment in the classroom. In fact, these elements are utterly important, especially in the case of language learning sessions where learners could easily lose their concentration due to short attention span. This is commonly seen during long periods of second language learning classes. Thus, using language learning games that contain detailed linguistic contents can be helpful. This can also motivate pupils who are driven by external components to use these games in proper contexts (Godwin-Jones, 2014).

Moreover, past researchers also believed that games can help teachers to create various meaningful contexts in which pupils can apply the usage of the language for communication in terms of exchanging information and expressing their own ideas especially in the spelling of new vocabularies (Derakhshan \& Khatir, 2015). Therefore, it is evident that by combining learning and playing through games and using other technologies in their learning environments, 
great impacts on pupils can be seen in their learning process. Kalaycioglu (2011) clearly stated that games used are always pupil-centered and they can be adjusted to be in sync with the learning objectives, age of learners and the children's level of proficiency. In short, through vocabulary games, learners will be more enthusiastic in learning vocabulary as games provide a multimedia context that engages the learners in vocabulary and key sentences (Derakhshan \& Khatir, 2015; Segal-Drori et al., 2010).

Besides, the usage of games is also effective in learning vocabulary because they usually involve friendly and healthy competition among learners and create a cooperative learning environment for the pupils (Calvo-Ferrer, 2015). Hence, using games in teaching vocabulary is more attractive for children and motivates them to improve their English vocabulary. In fact, games help young learners to learn vocabulary with more motivation compared to traditional teaching ways (Tüzün et al., 2009). Al Neyadi (2007) stated that motivation is one of the important factors in learning a language. A supportive environment that stimulates and engages the pupils in the learning process can ensure active participation in the learning of new vocabularies. Furthermore, Tsai (2012) mentioned that games can also enable children to overcome their learning problems and increase their motivation and confidence. Therefore, the Pocable game is used to enhance vocabulary skills among English language learners.

\section{Methodology}

\subsection{Research Design}

This is a quasi-experimental method type of research design. It incorporated the pre-test and post-test design to evaluate the effectiveness of a treatment or any educational intervention towards the respondents.

\subsection{Research Respondents}

According to Etikan, Musa and Alkassim (2016), purposive sampling is one of the sampling techniques in which the samples are not given equal chances of being included in the research. In fact, purposive sampling is a technique of selecting a sample of a population in order to determine the parameters of the whole population. It is an intentional selection of a respondent based on the characteristics the respondent possesses. Meanwhile, purposive sampling is also a non-random technique which is not restricted to a set number of respondents and includes any underlying theories.

Purposive sampling was used as the respondents were only chosen from low to intermediate level of English proficiency. By implementing purposive sampling, 40 Primary 4 pupils were selected for this quasi-experimental research. This small sample size is effective to monitor the implementation process of the Pocable Game. The schools involved were SK Sungai Setulan, Bintulu, SK Sungai Selad, Bintulu, SK Kampung Bungai, Subis and SK Kampung Selanyau, Subis. The number of respondents in each school was ten pupils. The pupils chosen were of "Low Language Proficiency" to "Average Language Proficiency" of four different rural schools in Sarawak ranging from Subis and Bintulu 
districts. Their level of proficiency was determined by their English language performance recorded in the School Based Assessment in the year 2019.

Table 1: Number of respondents

\begin{tabular}{|c|c|c|c|}
\hline The School (District) & Male & Female & Total number of respondents \\
\hline A (Bintulu) & 4 & 6 & 10 \\
\hline B (Bintulu) & 3 & 7 & 10 \\
\hline C (Subis) & 6 & 4 & 10 \\
\hline D (Subis) & 2 & 8 & 10 \\
\hline \multicolumn{2}{|r}{ Total } & $\mathbf{4 0}$ \\
\hline
\end{tabular}

\subsection{Research Instrument}

Three research instruments were used in this research. They were pre-test, posttest and followed by a survey questionnaire. Similar 20 spelling test and 20 matching words with their meanings were included in the pre-test and post-test (Appendix 1). After the implementation of the Pocable Game and Pear Deck, respondents were given a survey questionnaire (Appendix 2) regarding the intervention that they had experienced. The survey questionnaire consisted of five statements and each respondent was required to tick "agree" or "disagree" based on their personal experience of using Pocable Game and Pear Deck. The questionnaire was set to measure the pupils' learning motivation on vocabulary. It was adapted from the measures developed by Pintrich and DeGroot (1990), which also focuses on evaluating the learners' learning motivation.

\subsection{Research Procedure}

Before the intervention was implemented, a pre-test was conducted towards the respondents and the results were gathered and analysed. All the 20 targeted vocabularies were introduced by the researchers to the respondents using flash cards and word cards. In fact, all the 20 targeted vocabularies were introduced in four periods of lesson, where 5 vocabularies were introduced in each period of the lesson. After the $4^{\text {th }}$ period of lesson, the pupils have covered all the 20 vocabularies by using flash cards. Then, the respondents were given 13 random Pocable Game cards. They were required to form a word of at least four letters that they have learned. Respondents were then required to read, spell and explain the meaning of the words that they had formed. Marks on the top right corner of the card were added and respondents had to jot down all vocabularies formed in their mini vocabulary book. The game would end once a single respondent had placed all of their cards and the respondent with the highest score wins. As enrichment activities after Pocable Game, the respondents were introduced to Pear Deck; an interactive online platform used to actively engage pupils in individual and social learning. Pear Deck was integrated to assist the pupils to remember better the vocabularies that they had learned using the Pocable Game. 


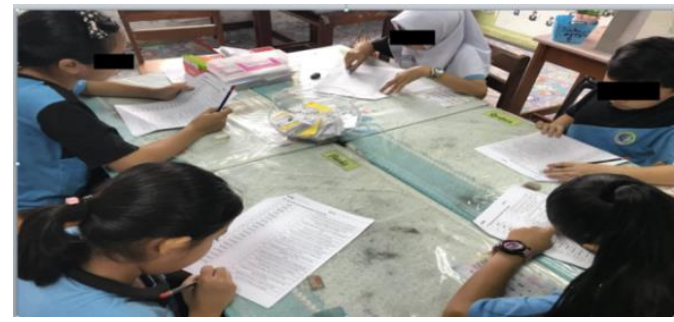

Figure 1: Pre-test was conducted before the intervention.

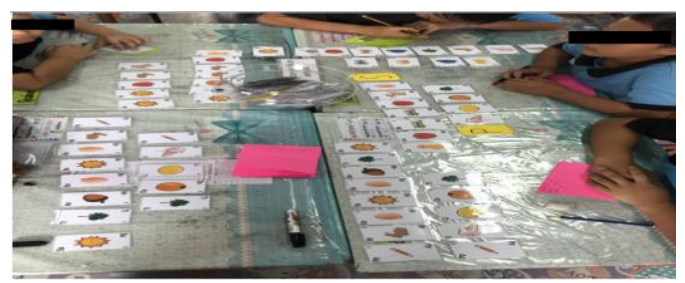

Figure 3: Each respondent was given 13 cards at random.

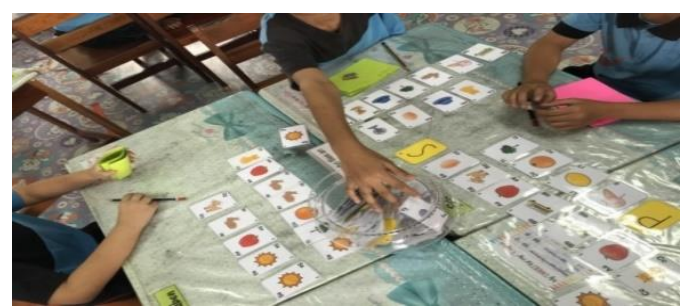

Figure 5: Respondents read, spelled and explained the meaning of the word to obtain marks.

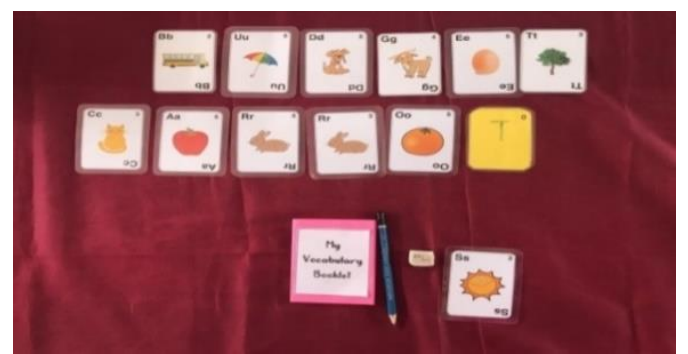

Figure 7: All the vocabularies formed were jotted down in the vocabulary booklet.

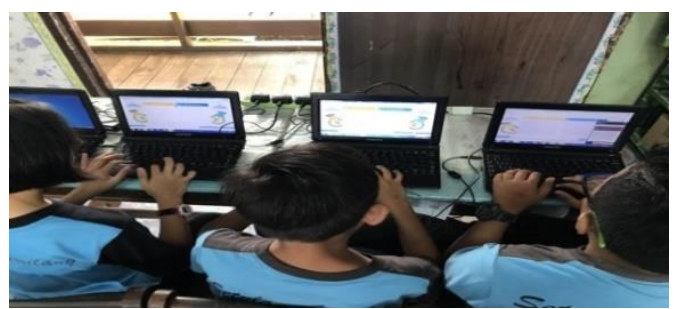

Figure 9: Pear Deck was used as an enrichment to help the respondents to retain the vocabularies learned.

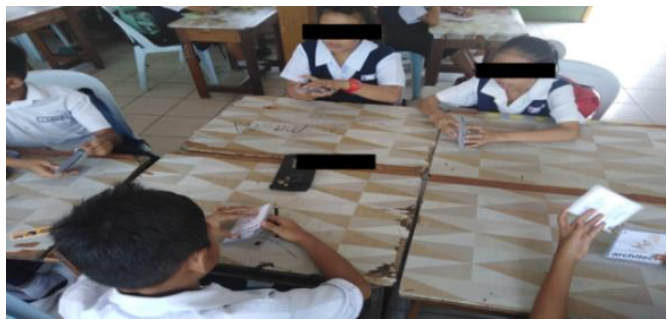

Figure 2: Teacher introduced 20 targeted vocabularies using flash cards and word cards.

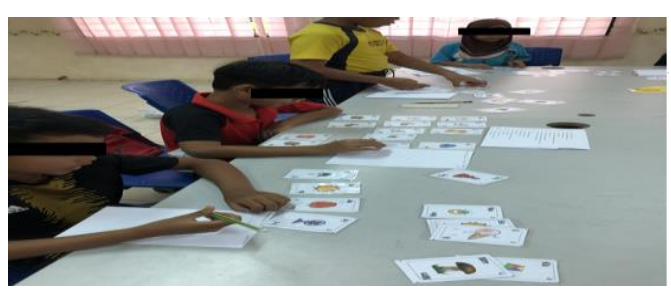

Figure 4: Respondents formed at least four letters of words that they have learned.

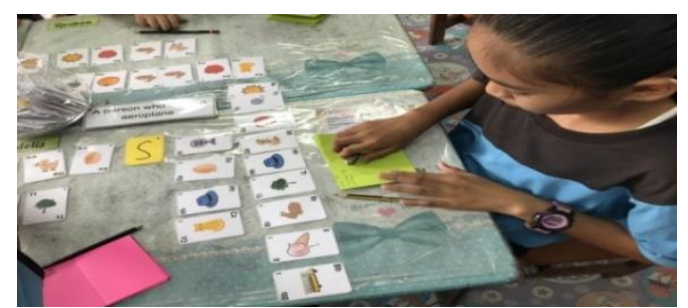

Figure 6: Respondents added up their marks on the top right corner of the card.

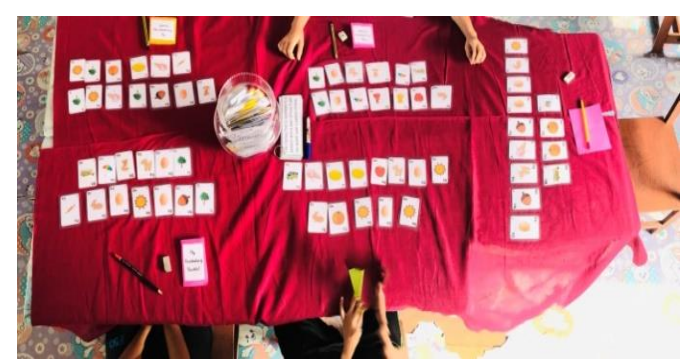

Figure 8: The game ended when one respondent had placed all of his cards. Respondent with highest score won.

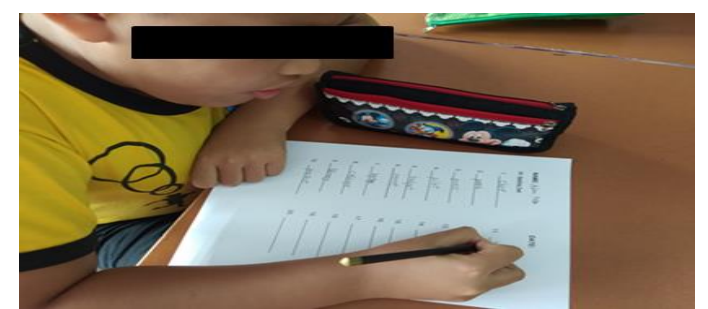

Figure 10: Post-test was conducted after four weeks of intervention. 


\subsection{Data Collection and Analysis}

The three research instruments, mainly the pre-test, post-test and survey questionnaire were used to collect data. All of the data collected were tabulated and analysed descriptively. The scores of all 40 pupils in their pre-test were compared to their scores in the post-test. The scores were calculated according to the percentage score formula. The scores were then analysed and placed with reference to the Criterion Referenced Assessment (CRA) which was used in the Malaysian Primary School Achievement Test to determine the comprehension level of respondents based on the scores collected through the pre-test and posttest. The CRA was first introduced in the United Stated in 1960s as a demand in determining the grade of a learner against a set of qualities or criteria, without reference to other individuals' achievement (Hambleton \& Li, 2014; Lok, McNaught \& Young, 2016). Pupils with test scores of 80 to 100 were categorised as Excellent and had successfully attained the highest level of vocabulary comprehension, followed by the test scores from 65 to 79 in the Good level, 50 to 64 in the Satisfactory level and 40 to 49 achieving Minimum level. Lastly, the scores from 0 to 39 indicated Failure and the lowest level of vocabulary comprehension. Table 2 shows the Criterion Referenced Assessment (CRA) used for both the pre-test and post-test.

Table 2: Criterion Referenced Assessment (CRA)

\begin{tabular}{|c|c|l|c|}
\hline Score & Grade & \multicolumn{2}{|c|}{ Descriptor } \\
\hline $80-100$ & A & Excellent & PASS \\
\hline $65-79$ & B & Good & PASS \\
\hline $50-64$ & C & Satisfactory & PASS \\
\hline $40-49$ & D & Achieve Minimum Level (Adequate) & PASS \\
\hline $0-39$ & E & Below Minimum Level (Poor) & FAIL \\
\hline
\end{tabular}

The survey questionnaires were analysed descriptively. There were five statements in the survey questionnaire and respondents were required to tick "Agree" or "Disagree" based on the statements. The number of respondents who "Agree" or "Disagree" with the statements were counted and converted into percentage form.

\section{Findings}

The data had been collected through pre-test, post-test and survey questionnaire. After identifying the pupils' scores, the scores were then analysed and placed with reference to the Criterion Referenced Assessment (CRA). CRA had been accepted world-wide and for this research, CRA based on the Malaysian Primary School Achievement Test would be used to determine the vocabulary skills of the pupils based on the scores collected through the pre-test and posttest. Table 3 and Figure 11 showed the descriptive statistics of the data collected from both the pre-test and post-test. 
Table 3: Results of the Pre-test and Post-test

\begin{tabular}{|c|c|c|c|}
\hline \multirow{2}{*}{ Score } & \multirow{2}{*}{ Grade } & \multicolumn{2}{|c|}{ Number of Pupils } \\
\cline { 3 - 4 } & & Pre-test & Post-test \\
\hline $80-100$ & A & 1 & 30 \\
\hline $65-79$ & B & 2 & 10 \\
\hline $50-64$ & C & 1 & 0 \\
\hline $40-49$ & D & 30 & 0 \\
\hline $0-39$ & E & 6 & 0 \\
\hline
\end{tabular}

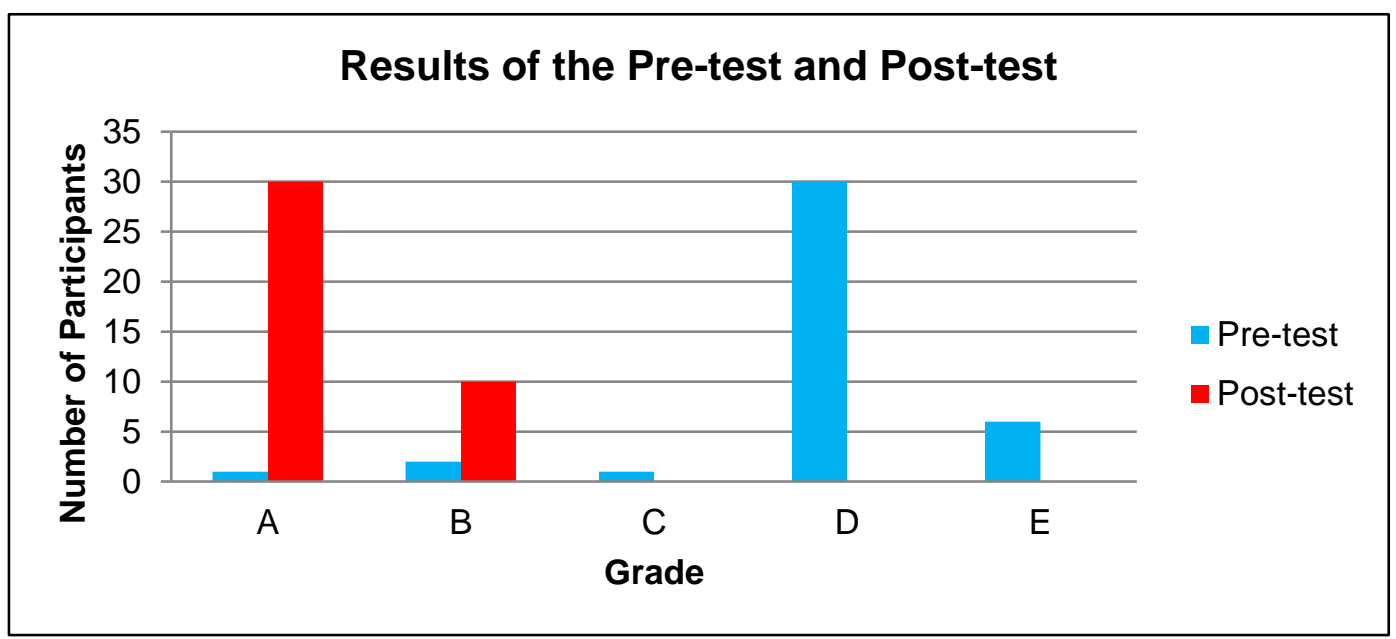

Figure 11: Respondents' scores in the pre-test and post-test

In Table 3 and Figure 11, there was an improvement in the results of the respondents' post-test. As for grade A, there was one respondent who managed to obtain grade $\mathrm{A}$ but in the post-test, there were 30 respondents managed to get grade A. As for grade B, only two respondents obtained the grade in the pre-test, while in the post-test, there were 10 respondents who managed to obtain the grade. This showed an increase by 8 respondents, who had grade B. There was one respondent who got grade $C$ in the pre-test, whereby in the post-test, none of the respondents got grade $\mathrm{C}$. This implied that the use of Pocable Game and Pear Deck managed to enhance the vocabulary skills among the learners. 30 respondents scored grade $\mathrm{D}$ in their pre-tests while none of the respondents received this grade in the post-test. This is the same for grade E, where six respondents had grade $\mathrm{E}$ in the pre-test, but none of them obtained the same grade in the post-test. The results showed that the Pocable Game and Pear Deck were able to enhance the vocabulary skills among the learners. All the respondents obtained a good grade and they showed improvements in their vocabulary learning.

Moreover, Table 4 describes the descriptive statistics of the data collected from the survey questionnaire gauging on the improvement in vocabulary skills, collaboration and motivation aspects after the implementation of Pocable Game and Pear Deck. 
Table 4: Data Collected from the Survey Questionnaire $(n=40)$

\begin{tabular}{llcc}
\hline NO. & \multicolumn{1}{c}{ STATEMENTS } & $\begin{array}{c}\text { AGREE } \\
\boldsymbol{n}(\%)\end{array}$ & $\begin{array}{c}\text { DISAGREE } \\
\boldsymbol{n}(\%)\end{array}$ \\
\hline 1. & $\begin{array}{l}\text { I have fun while playing the Pocable } \\
\text { Game and Pear Deck. }\end{array}$ & $38(95)$ & $2(5)$ \\
2. $\quad \begin{array}{l}\text { I help my friends who cannot give the } \\
\text { meaning of the vocabularies that they } \\
\text { have formed. }\end{array}$ & $36(90)$ & $0(0)$ \\
3. $\quad \begin{array}{l}\text { I know how to spell the vocabularies that } \\
\text { I have learned. }\end{array}$ & $40(100)$ & $0(0)$ \\
4. $\quad \begin{array}{l}\text { I can remember the meaning of the } \\
\text { vocabularies learned. }\end{array}$ & $40(100)$ & $0(0)$ \\
5. $\quad \begin{array}{l}\text { I am interested to play the Pocable Game } \\
\text { and Pear Deck. }\end{array}$ & $40(100)$ & \\
\hline
\end{tabular}

As illustrated in Table 4, Question 1 and 5 focused on the respondents' motivational level while Question 2 focused on the respondents' collaborative skills throughout the Pocable Game and Pear Deck. On the other hand, Question 2 and 3 emphasised on the improvement in vocabulary skills after the implementation of Pocable Game and Pear Deck.

Based on the motivational level as per implementation of the Pocable Game and Pear Deck, 95\% of the respondents agreed with the aspect of "I have fun while playing the Pocable Game and Pear Deck" while $100 \%$ of the respondents agreed with the statement of "I am interested to play the Pocable Game and Pear Deck". The two statements highlighted that the learners were highly motivated and enthusiastic while learning vocabularies through Pocable Game and Pear Deck as compared to the traditional chalk and talk method.

On the aspect of collaboration, $90 \%$ of the respondents agreed to the statement of "I help my friends who cannot give the meaning of the vocabularies that they have formed". This showed that the respondents were willing to collaborate with their peers in learning vocabularies through Pocable Game and Pear Deck. Through collaborative learning, the pupils would be able to develop $4 C^{\prime} s$ (cooperation and collaboration, communication, creative and critical thinking skills) and $1 \mathrm{~V}$ (value) in this $21^{\text {st }}$ century education system as stated in the Malaysia Education Blueprint 2013 - 2025 (Ministry of Education, 2015).

For the aspect of improvement in vocabulary skills, 100\% of the respondents agreed to both the statements of "I know how to spell the vocabularies that I have learned" and "I can remember the meaning of the vocabularies learned". Thus, these statements showed that through Pocable Game and Pear Deck, the respondents were able to remember the spelling and meanings of the vocabularies learned better.

All in all, the five statements from the survey questionnaire indicated that the learners gained positive and constructive experiences in enhancing their vocabulary skills and they were encouraged to learn more vocabularies using Pocable Game and Pear Deck. 


\section{Discussions}

\subsection{Enhancing the Vocabulary Skills among Learners}

From the pre and post-test result, it can conclude that the use of Pocable Game and Pear Deck managed to enhance the vocabulary skill among the Year Four respondents from four different schools. In the pre-test, majority of the research respondents scored less than $45 \%$. This indicated that the previous methods and techniques in teaching vocabulary were not effective. After the implementation of the Pocable Game and Pear Deck, the post-test showed a significant increase in the score of the research respondents. All 40 respondents had scored $100 \%$ in their post-tests. This showed that the incorporation of the Pocable Game with Pear Deck managed to reinforce the vocabularies learned among the pupils, which also adhered to the aim of this paper. Undeniably, according to Takeuchi and Vaala (2014), playing games which are educational to pupils would give a chance for them to experience a more positive and encouraging learning environment. Through the post-test, it was also found that using the Pocable Game could enhance the pupils' ability in memorising new vocabularies and encourage the pupils' interaction in remembering the spelling and the meaning of the vocabularies. Vygotsky (1978) mentioned that games help in developing problem solving skills and enhances the creativity and communication among primary pupils. The pupils have to put in effort to remember not only the spelling of the vocabularies but the meanings too. Past researchers also believed that the use of games could help teachers to create various contexts in which pupils can use the language for communication, exchange information and express their own opinions especially in the spelling of new vocabularies (Derakhshan \& Khatir, 2015). Besides, the survey questionnaire showed positive responses from the research respondents. It showed that all of the pupils agreed that they know how to spell and remember the meanings of the words that they had learned. This showed the effectiveness of using games in developing the pupils' vocabulary skill. Moreover, Taghiadeh et al. (2017) also supported that the use of games enables children to learn vocabulary better than using traditional ways. Therefore, it could be concluded that the use of Pocable Game and Pear Deck is effective in enhancing the learners' vocabulary skills.

\subsection{Encouraging the Learners to Learn Vocabularies}

From the survey questionnaire, it showed that the Pocable Game and Pear Deck had achieved its potential in encouraging learners to learn vocabularies. The research respondents showed positive responses as majority of them agreed to the statements in the survey questionnaire. The research respondents agreed that they were interested and had fun playing the Pocable Game and Pear Deck. This showed that learners were motivated to learn new vocabularies after the implementation of the Pocable Game and Pear Deck. According to Al Neyadi (2007), motivation is one of the important factors in learning a language and a supportive environment that stimulates and engages the pupils in learning will ensure active participation in the learning of new vocabularies.

Apart from that, it was also found that most of the respondents collaborated with their peers by helping them in giving the meaning of the vocabularies 
formed. Games are effective in learning vocabulary because they "usually involve friendly competition and create cooperative learning environment to the pupils" (Derakhshan \& Khatir, 2015). The communication between the learners showed that they were interested and participated actively in the learning process. It was a learner-centred activity and provided a meaningful experience to the pupils as they interacted with each other and as a result, the acquisition of language vocabulary was encouraged (Segal-Drori et al., 2010). Therefore, it could be concluded that Pocable Game and Pear Deck managed to encourage pupils to interact with each other and to participate actively in the learning of new vocabularies. This is supported by Shahriarpour and Kafi (2014) who stated that using games makes pupils participate actively in this $21^{\text {st }}$ century technological society. Another distinct game-based learning vocabulary activity which was conducted by Shabaneh and Farrah (2019) also supported that the learners were exposed with learning vocabulary through games to improve their reading and spelling of the vocabularies. Findings showed that the learners were able to enjoy while learning and show great improvements.

\section{Conclusion and Implications}

The use of Pocable Game and Pear Deck can help to enhance the pupils' vocabulary skills. In this research, it was proven to be effective as the data collected from the pre-test, post-test and survey questionnaire showed that majority of the respondents had positive experiences in learning vocabulary through the Pocable Game and Pear Deck, aside from having better memory retention of the vocabularies learned; in which promoted the learners' interest in expanding their vocabulary bank. The pupils' level of motivation was observed to be improving and they provided positive feedbacks to the use of Pocable Game and Pear Deck in learning new vocabularies. For pupils, the use of Pocable Game incorporated with Pear Deck is a fun and interactive way in learning new vocabularies without fully depending on memorising and drilling. In fact, the 4C's and $1 \mathrm{~V}$ could also be enhanced among pupils, in line with the current $21^{\text {st }}$ century learning system.

As for teachers, it provides a platform for a pupil-centred learning environment where pupils can carry out the activities through hands-on activity. This reduced the teacher's involvement in the learning process and allowed more autonomy for the pupils in learning the new and unfamiliar vocabularies. As independent word learners, pupils will learn best by making sense of their own vocabulary and internalising it. Through the usage of the Pocable Game, the teacher is only required to monitor the pupils' learning. Thus, Pocable Game and Pear Deck shows the relevance to the improvement in the methodology of teaching vocabulary in a fun, interesting and meaningful way. As suggestions for future researches, it would be interesting to see the incorporation of other various technology-based applications such as Quizizz, Kahoot, and Quick Response (QR) codes alongside open-ended written questions, observations and openended interviews. 


\section{References}

Al Neyadi, O. (2007). The effects of using games to reinforce vocabulary learning. In H.C.T. Marifa (Ed.), Action research and initial teacher education in the UAE (pp. 99107). HCT Press, UAE.

Bakhsh, S. A. (2016). Using games as a tool in teaching vocabulary to young learners. English Language Teaching, 9(7), 120-128. doi:10.5539/elt.v9n7p120

Calvo-Ferrer, J. R. (2017). Educational games as stand-alone learning tools and their motivational effects on L2 vocabulary acquisition and perceived learning gains. British Journal of Educational Technology, 48(2), 264-278. https://doi.org/10.1111/bjet.12387

Chirandon, A., Laohawiriyanon, C., \& Rakthong, A. (2010). The effects of teaching English through games. Retrieved September 26, 2019, from http://fs.libarts.psu.ac.th/research/conference/proceedings-2/4pdf/006.pdf

Derakhshan, A., \& Khatir, E.D. (2015). The effects of using games on English vocabulary learning. Journal of Applied Linguistics and Language Research, 2(3), 39-47.

Etikan, I., Musa S. A., \& Alkassim, R. S. (2016). Comparison of convenience sampling and purposive sampling. American Journal of Theoretical and Applied Statistics, 5(1), pp. 1-4. doi:10.11648/j.ajtas.20160501.11.

Gee, J. P. (2012). The old and the new in the new digital literacies. The Educational Forum, $76(4), 418-420$.

Godwin-Jones, R. (2014). Games in language learning: Opportunities and challenges. Language Learning \& Technology, 18(2), 9-19 Retrieved from http://llt.msu.edu/issues/june2014/emerging.pdf

Hambleton, R. K., \& Li, S. (2014). Criterion-referenced assessment. Wiley StatsRef: Statistics Reference Online 1-8.

Hashim, H., Rafiq, K. R. M., \& Yunus. (2019). Improving ESL learners' grammar with gamified-learning. Arab World English Journal (AWEJ) Special Issue on CALL, (5), 41-50. doi:10.24093/awej/call5.4

Indriyani, A., \& Sugirin. (2019). The impact of vocabulary learning strategies. 3rd International Conference on Current Issues in Education (ICCIE 2018) (pp. 113-117). Paris: Atlantis Press.

Kalaycioğlu, H. E. (2011). The effect of picture vocabulary games and gender on four years old children's English vocabulary performance: An experimental investigation (Unpublished master's thesis). Middle East Technical University, Turkey.

Kunnu, W., Uiphanit, T., \& Sukwises, A. (2016). The development of vocabulary memorization by using games. International Journal of Social Science and Humanity, 6(6), 419-422. Retrieved from http://www.ijssh.org/vol6/683-H019.pdf

Lie, W., \& Yunus. (2018). Pen pals are now in your fingertips - A global collaboration online project to develop writing skills. Creative Education, 9(15), 2491-2504. doi:10.4236/ce.2018.915188

Lok, B., McNaught, C. \& Young, K. (2016). Criterion-referenced and norm-referenced assessments: Compatibility and complementarity. Assessment $\mathcal{E}$ Evaluation in Higher Education, 41(3), 450-465. doi:10.1080/02602938.2015.1022136

McKay, S. L. (2018). English as an international language: What is it and whta it means for pedagogy. RELC Journal, 49(1), 9-23.

Ministry of Education. (2015). English language education reform in Malaysia: The roadmap 2015-2025. Retrieved September 10, 2019, from https://anyflip.com/detl/zspi/basic 
Noureddine, A. (2017). The benefits of using ICT in the EFL classroom: From perceived utility to potential challenges. Journal of Educational and Social Research, 7(1), 111118.

Pintrich, R. R., \& DeGroot, E. V. (1990). Motivational and self-regulated learning components of classroom academic performance. Journal of Educational Psychology, 82, 33-40.

Pomerantz, A., \& Bell, N. D. (2007). Learning to play, playing to learn: FL learners as multicompetent language users. Applied Linguistics, 28(4), 556-578.

Reddy, M. S. (2016). Importance of English language in today's world. International Journal of Academic Research, 3(4), 179-184.

Segal-Drori, O., Korat, O., Shamir, A., \& Klein, P. S. (2010). Reading electronic and printed books with and without adult instruction: Effects on emergent reading. Reading and Writing, 23(8), 913-930.

Shahriarpour, N., \& Kafi, Z. (2014). The effect of playing digital games on Iranian intermediate ELF learners' motivation toward learning English vocabularies. Procedia-Social and Behavioural Sciences, 98, 1738-1743.

Taghiadeh, M., Vaezi, S., \& Ravan, M. (2017). Digital games, songs and flashcards and their effects on vocabulary knowledge of Iranian preschoolers. Studies, 5(4), 156171.

Takeuchi, L. M., \& Vaala, S. (2014). Level up learning: A national survey on teaching with digital games. New York: The Joan Ganz Cooney Center at Sesame Workshop.

Thirusanku, J., \& Yunus. (2012). Status of English in Malaysia. Asian Social Science, 10(14), 254-260. ISSN 1911-2017.

Tsai, F. H., Yu, K. C., \& Hsiao, H. S. (2012). Exploring the factors influencing learning effectiveness in digital game-based learning. Educational Technology $\mathcal{E}$ Society, 15(3), 240-250.

Tüzün, H., Yılmaz-Soylu, M., Karakuş, T., İnal, Y., \& Kızılkaya, G. (2009). The effects of computer games on primary school students' achievement and motivation in geography learning. Computers $\mathcal{E}$ Education, 52(1), 68-77.

Viera, R. T. (2016). Vocabulary knowledge in the production of written texts: A case study on EFL language learners. Revista Tecnologica ESPOL, 30(3), 89-105.

Vygotsky, L. (1978). Interaction between learning and development. California: W. H. Freeman Company.

Wang, C. K. J., Khoo, A., Liu, W. C., \& Divaharan, S. (2008). Passion and intrinsic motivation in digital gaming. Cyber Psychology \& Behaviour, 11(1), 39- 45.

Yunus \& Ek Hern, G. (2011). Malaysian undergraduates' perceptions and attitudes on bilingual education. Procedia Social and Behavioural Sciences, 15, 2618-2622.

Yunus, M., Lau, E. Y. Y., Khair, A. H. M., \& Yusof, N. M. (2020). Acquisition of vocabulary in primary schools via GoPic with QR code. International Journal of English Language and Literature Studies, 9(3), 121-131. doi: 10.18488/journal.23.2020.93.121.131.

Yunus, Nordin, N., Salehi, H., Embi, M. A., \& Salehi, Z. (2014). Future of ICT as a pedagogical tool in ESL teaching and learning. Research Journal of Applied Sciences, Engineering and Technology, 7(4), 764-770. 
Appendix 1: Pre-test and Post-test

\section{(A) Spelling Test}

1.

2.

3.

4.

5.

11.

12.

13.

14.

15.
6.

7.

8.

9.

10.

16.

17.

18.

19.

20.

(B) Write down the correct numberin the bracket.

\begin{tabular}{|c|c|c|c|c|}
\hline 1 & chef & & & A prolessional cook who works in a restaurant. \\
\hline 2 & park & & & A person who travels and works in a spacecraft. \\
\hline 3 & grass & & & $\begin{array}{l}\text { A person who designs and builds engines. } \\
\text { machines, roads and bndges. }\end{array}$ \\
\hline 4 & pilot & ( & & $\begin{array}{l}\text { A public place where people go to walk, play and } \\
\text { retax. }\end{array}$ \\
\hline 5 & budget & ( & & A person who designs buildings. \\
\hline 6 & carrot & ( & ) & A wild plant with narrow green leaves. \\
\hline 7 & laptop & & & $\begin{array}{l}\text { The money that is available to a person and a plan } \\
\text { of how it will be spent over a penod of time. }\end{array}$ \\
\hline 8 & cabbage & & & A long pointed orange root vegetable. \\
\hline 9 & library & & ) & $\begin{array}{l}\text { A round vegetable with large green, purplish-red or } \\
\text { white leaves that can be eaten raw or cooked. }\end{array}$ \\
\hline 10 & present & & & \\
\hline 11 & racquet & 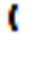 & ) & be easilly camed. \\
\hline 12 & village & ( & ) & $\begin{array}{l}\text { A building where you can read or borrow books. } \\
\text { new spaper and CUs. }\end{array}$ \\
\hline 13 & ambition & ( & ) & Agin \\
\hline 14 & birthday & & & A prece of sport equipment used lor hirting the ball. \\
\hline 15 & engineer & & & A very small town located in a country area. \\
\hline 16 & $d$ & & & Something that jou want to do or achieve. \\
\hline & UCIItIst & & & I he day when you are born. \\
\hline 17 & architect & & & A person who takes care of others" teeth. \\
\hline 18 & astronaut & & ) & $\begin{array}{l}\text { A system for carrying people or goods from one } \\
\text { place to another. }\end{array}$ \\
\hline & & & ) & Matenals lor writing or using in the ofthce. \\
\hline 20 & stationery & & ) & A person who thi \\
\hline
\end{tabular}




\section{Appendix 2: Survey Questionnaire Instruments}

\begin{tabular}{|c|c|c|c|}
\hline NO. & STATEMENTS & AGREE & DISAGREE \\
\hline 1. & $\begin{array}{l}\text { I have fun while playing the Pocable } \\
\text { Game and Pear Deck. }\end{array}$ & & \\
\hline 2. & $\begin{array}{l}\text { I help my friends who cannot give the } \\
\text { meaning of the vocabularies that they } \\
\text { have formed. }\end{array}$ & & \\
\hline 3. & $\begin{array}{l}\text { I know how to spell the vocabularies } \\
\text { that I have learned. }\end{array}$ & & \\
\hline 4. & $\begin{array}{l}\text { I can remember the meaning of the } \\
\text { vocabularies learned. }\end{array}$ & & \\
\hline 5. & $\begin{array}{l}\text { I am interested to play the Pocable Game } \\
\text { and Pear Deck. }\end{array}$ & & \\
\hline
\end{tabular}

